\title{
The rise and fall of professional singers: A typology of creative career stages in the performing arts
}

Kathleen Connell, Andrew R. Brown and Sarah Baker (Griffith University, Australia)

\begin{abstract}
Creative careers in the performing arts follow a somewhat unique trajectory that is driven by specific labour market conditions. This chapter outlines a typology of creative career stages as they have become evident in our explorations of the career trajectories of professional singers. The career stages we propose are: (1) pre-career; (2) breaking in; (3) the peak period; (4) denouement; (5) new directions. While our primary data relates specifically to singers, our experience and related literature suggests that lessons learned here should apply to performing arts careers more broadly. Creativity and identity are tightly intertwined for the professional singers and when seeking new directions following the denouement stage, the majority of singers in our study attempted to remain attached to an artistic field even when they accept that their time as a professional singer has passed. By focusing on the subjective experiences of professional singers, the chapter highlights that creative careers are difficult to sustain and that the fragility of the creative career, once realized, can have very real implications for the wellbeing of the creative professional given the extent to which their identity is tied up with their profession and the pursuit of creativity. The chapter also highlights that career trajectories in professional singing, and the performing arts more broadly, follow a distinctive arc because this labour force is creatively embodied. The chapter argues that it is only in the consideration of the lifecycle of the creative performance career that the critical link between pre- and post-career stages can be made. An implication of this study is that training for creative careers, particularly those focused on professional singing, must encompass more than perfecting the technical skills of the craft to include a capacity for medium-term career planning in order that new directions are be more seamlessly engaged with following career denouement. As such, there must be more to the creative career than an impetus for creativity.
\end{abstract}

Keywords: performance, career, singing, creativity, career stages, music, singers

\section{Introducing Creative Careers}

The identification of creative careers has been popular in recent times but studies that focus on careers in the creative arts, and performing arts careers specifically, are still fairly limited. Performing arts careers encompass those creative practices performed for an audience including, for example, acting, circus arts, musical performance, theatre and classical singing. Pursuing particular forms of creativity in the performing arts may take a circuitous route to a 
vocational outcome yet few studies have investigated this proposition, especially amongst the many performing artists who are the mainstay of arts organizations across geographies that chart the spaces and places of our communities. In this chapter, we argue that while the impetus for creativity may be shared by a range of industries, the embodied characteristics of the performing arts is an important additional consideration in the analysis of career trajectories in professions that emphasize and are underpinned by the pursuit of creativity.

This chapter explores performing arts careers by drawing specifically on a qualitative study of 13 elite classical singers interviewed between 2011 and 2012 to consider how creative careers can be understood to follow a trajectory of development and decline. The singers were all based in Australia at the time they were interviewed and each identified as being past the peak period of their careers in this industry. The value of interviewing older, post-denouement creative workers is in the opportunity to understand how the lifespan of creative careers unfolds after a stage of decline. Based on the narratives of their subjective experiences of their working lives, in this chapter we put forward a typology of the stages of performing arts careers. Our typology is underpinned by an understanding that the trajectories experienced by the singers in this study are somewhat representative of the career trajectories of performing artists more broadly, and that their narratives would share many traits with creative careers in general. The chapter outlines the stages of this trajectory, which we propose encompasses: (1) pre-career; (2) breaking in; (3) the peak period; (4) denouement; and (5) new directions. Before turning to this framework, we first outline the impetus for creativity, the embodiment of creativity in performing arts careers, and how these are tied into the identity of performers. Offering such a background is important for providing the context through which the rise and fall of a career as an elite classical singer is negotiated by those we interviewed.

\section{The impetus for creativity}

The catalyst to pursue a career as an elite classical singer may have many stimulants and impulses. However, a consistent component is the individual's inner drive to master the complex and challenging skills of the singing style required to compete in a work environment that is characterized by embodied virtuosity achieved through extended training, an incessant search for quality projects, intense competition for limited work opportunities, uncertain employment security, and vocational environments with dynamic management changes. Resources are often limited and demand the coordination of many skilled artisans acting with 'mutual responsibility' and a need to balance 'unpredictable and rapidly shifting consumer demands' (Jones, 1996: 60 ). Despite this somewhat unattractive employment context, and perhaps in part because of ignorance of its challenges, people continue to be motivated to pursue careers in the performing arts.

It has long been recognized that creative pursuits often correspond with intense ambitions. Hallman, as early as 1965 , made this clear stating that 'the one generalization which the data support is that strong motivation is indeed a major component of creativity' (Hallman, 1965: 454). After surveying psychological and psychoanalytic literature of the time, Hallman goes on to suggest that creative artists display an 'aesthetic motivation' driven more by qualitative responses to the world than by pragmatic qualities such as survival. 
The impetus for creativity can be evident early in life (McPherson et al., 2012; McPherson \& Welch, 2012) and is apparent in our own data. The elite classical singers in our study identified early adolescence as the age at which their motivation to seek creativity through music and song was realized. An environment that nurtures music and its performance can develop an individual's propensity for lifelong engagement and propel individuals on to more advanced stages of competency. Finding boundless, yet subtle personal significance in the craft of singing and the sounds produced can fill an individual with a satisfaction that compels them to commit to honing the craft of singing and casting themselves into a journey toward an elite career in the field of performance.

Developmental projects in which to live out one's creativity in the field of classical singing are important stepping stones from early expressive engagement toward a professional career. Such projects can vary from community choirs singing ancient vocal works to amateur stage shows featuring the contemporary composers of blockbuster music theatre productions. In our study of the career trajectories of elite classical singers, we found that community music groups were often the nurseries (Bartleet et al. 2008) in which emerging singers begin to signal their skills, learn theatrical processes, and drive their passion for singing and performance. Choral groups, music theatre organizations of varying hues, community concerts and competitive singing such as eisteddfods, form some of the tentative paths singers use to explore their passion and develop skills. These experiences intensify the initial creative impulse and reinforce social and cultural compulsion to continue developing the practice (Bartleet et al., 2008;

Coffman and Higgins, 2012).

\section{Embodied creativity and performing arts}

Practices in the performing arts are forms of creativity that are the work of bodies (Daykin, 2005; Pettinger, 2015). Elite singers develop powerful understandings about the way in which their bodies operate in order to sing music which is often unamplified, competing with in excess of 60 orchestral musicians, and which is regularly performed in lofty and extravagant architectural spaces. As well, to perform successfully and convincingly requires a deft use of movement, gesture, appropriate facial shaping and a myriad of stage presentation skills. Other demands required to gain and sustain professional hirings, include collaboration with other high level arts practitioners, meeting the publicity expectations of management and audiences, and maintaining the singer's own intense conscientiousness regarding the quality of their work; which they measure against their competitors and peers (Hesmondhalgh, 2007; Jones, 1996; Ryan, 2002).

Elite classical singers master detailed skills that are built through repetitive muscle actions, creating deep muscle memories which are wired to a finely-tuned cognitive understanding of musical processes and conventions. Singers' voices and bodies become conduits for varied sonic timbres, symbols of texts, and performance actions that combine to form some of humankind's richest sonic and storytelling offerings (Hesmondhalgh, 2007; Robinson and Aronica, 2011).

The significance of an embodied practice on career development can also be found in career studies in the sports and dance fields. These fields have acknowledged that the career span of 
their elite practitioners will most likely peak as the performer reaches a physical and mental maturity for the intense level of competition expected (Baillie, 1993; Grove et al., 1997; Jeffri and Throsby, 2006). The performers' training magnifies their commitment and specialization, bringing a sense of intense elation through the perfection of their skills. These personal motivations are enhanced by the specialized environment in which they perform, and the similar values and goals shared by those with whom they collaborate (Ensher et al., 2002; Jones, 1996; 2002; Oakland, 2010). Research shows that without awareness of forthcoming career events such as deselection, sudden injury, and the effects of ageing, the sports and dance practitioners would, like our singers, resist changes to their career, bargain against the loss of their positions in sport and artistic teams, and seek further opportunities to continue to work in a role that they feel can never be replicated (Baillie, 1993; Grove et al., 1997; Jeffri and Throsby, 2006). In Baillie's (1993) work on sports careers, he suggests that there are also serious transition periods for many sports practitioners. He writes, they often ask, 'Will I ever find anything that equals the pleasure, passion and intensity that I found in sports competition?' (Baillie, 1993: 405). Dancers express similar apprehensions according to Jeffri and Throsby (2006), who found that they were reluctant to discuss a probable career change for fear that such talk would jeopardize their dance work opportunities.

The singers in our study found they were faced with a variety of issues regarding their hoped-for longevity of career as classical singers. Popular and anecdotal writings often indicate that a long and fruitful career as a singer is a possibility (Colin, 2014; Plotkin, 2017; Simeonova, 2016) and the singers recalled previous generations of opera singers who enjoyed long lived careers.

There was a perception amongst the singers that as a voice matures different roles are accessible at a later age. Singers often begin their careers in their late twenties and this may lead to an expectation that a career will be sustained. Those that do sustain a career, however, are often very few in number. Our study found multifaceted issues can besiege singers as they try to maintain a healthy approach to their voices, appearance, and emotional and physical fitness. Performance roles in the strict classical world of singing are often categorized by a fach system - a method of classifying voices and which implies certain physical and vocal characteristics (Callaghan et al., 2012). While some voices are able to traverse different categories, those singers are a small subset of star performers (Hesmondhalgh, 2007). For singers in our Australian study we found the fach system had little apportionment, as strict role classifications were often straddled. For example, one interviewee noted, 'One night you would be singing a complex 20th century opera and the following a role in Verdi or Puccini ... In Australia you have to sing so much more. The new management said I fell into the cracks. They were using the fach system' (M/090911/1). For the large proportion of interviewees, loss of work was more aligned to the structure and vacillating nature of the labour market. Other factors included oversupply of competitors, shifting managerial and market perceptions, lifestyle questions (including family needs or a preference for a more settled life), and a stalled career trajectory that resulted in the singers becoming bored or frustrated with their career (Hesmondhalgh and Baker, 2011; Menger, 1999; Towse, 1993).

\section{Deep identity as a performer}

The intensive skill development in the performing arts, as just described, leads to an intense identification with the domain that manifests as a deep sense of identity as a performer and 
creative practitioner. It leads to strong social bonds with others who 'understand' these motivations and experiences. These traits are often seen in a positive light, as when Robinson and Aronica (2009) encourage the alignment of skills and interests as a way of providing fulfilment. They suggest that 'When people are in their Element, they connect with something fundamental to their sense of identity, purpose, and well-being' (Robinson and Aronica, 2009: 21). Yet research into cultural industry careers has also found that there can be dangers in defining oneself too much through creative work (Hesmondhalgh and Baker, 2011: 148). While it is recognized that over-identification can be experienced in all forms of work, cultural industry researchers argue that 'there are specific forms this kind of attachment takes in creative labour' (ibid.: 141).

Our study found that singers were resolute in their outlook on skill development and vocational intention, and developed an identification with craft and métier often to the exclusion of making well-judged career decisions. As we will outline in more detail later, the energy singers apply to maintaining their careers is testimony to their investment in a highly specialized skill set that was at the centre of their identity and work life. That in the face of, often dramatic, career changes none of the singers in our study sought counselling or was offered assistance seems distressing. As one singer commented, 'It was assumed you would just know what to do to get work' (F/010512/13). Whilst they each made heroic efforts to either survive or revive their careers, it was without support or guidance from either collective groups such as unions or from training and industrial institutions or private practitioners in psychological or career counselling fields. In the face of such dramatic change and isolation, and in the absence of understanding the dynamics of a performing arts career, the singers' identity shifted from being a positive influence through persistence and focus to a negative drag on the ability to imagine alternative futures.

\section{Career Lifecycle}

In order to understand how the impetus for creativity, its embodiment, and links to identity impact upon the development of a career in elite classical singing and the decline of the career, it is useful to think about how career progression occurs in stages which indicate the journey a singer takes as they create a career path to professional status. The stages we present here emerge from a thematic analysis of our participants' subjective experiences of their career trajectories. Five distinct stages emerged and we deal with each in turn below. However, it is also important to note that while these five stages can be recognized as discrete phases of career progression, the transition from one stage to the next is less distinct and only recognisable by the singers with the benefit of hindsight.

\section{Stage 1: Pre-career}

The relationships, influences and contexts that singers experience during their pre-career period are the strongest indicator of whether they will choose to pursue a career in professional 
singing (McPherson and Welch, 2012; McPherson et al., 2012). The singers in this study describe influential relationships within the family environment, musical communities, and with their singing teachers as having the most important impact on their pre-career experience.

The singers recollect that important individuals contributed to their musical development, and influenced their belief that they could be a professional singer. A singer's family, whether encouraging or complex, offered the most immediate source of this dynamic, and formed the basis of their pre-career development. Included in many family environments was the access to high-quality audio technology in the home, which allowed listening to established singers of international standard. One interviewee recalled, 'I can still see Dad waiting to collect the Reader's Digest recordings from the post. We loved listening together' (M/170412/12). Schooling was identified by a small number of our participants as being significant in their singing development, but for the majority schooling made an unmemorable contribution to their musical journey. Spruce and Odena (2012) have found that the influence of schools upon those interested in pursuing music is highly varied. Whilst school environments have the opportunity to inspire they are not necessarily the main source when investigating why some individuals pursue music.

Meaningful music-making happened in the community. Participation in community musicmaking was one of the strongest influences the singers described when discussing their precareer musical journeys. Performance communities gave the singers practice and experience in the operation of a concert and theatre making and provided opportunities to perform for audiences. Enabled by these community groups was access to the encouragement and influence of individuals who offered assistance, ranging from support after the early death of a parent to opportunities to sing the solos of the canon of works from the vocal repertoire. The influence of community continued into early adulthood. As one participant recalled, 'I loved the Gilbert and Sullivan shows at Uni. I met so many people who shared my love of music and performance' (F/220312/9). Often disregarded as 'amateur' performance groups, these communities fostered creativity and nurtured the desire of our interviewees to perform, providing positive pre-career experiences and support beyond just musical or career development (Bartleet et al., 2008).

Within this community context many of the singers participated in competitions or eisteddfods. Through these events singers learnt performance skills and met potential future colleagues, and a lucky few earned substantial funds to support further studies. Importantly, skills beget skills: success in these competitions increased the singers' desire to pursue the possibility of a career in the industry (McPherson et al., 2012; McPherson \& Welsh, 2012). Drawing inspiration from the community, the singers strove to invest time to learn the detailed skills required of a competent singer. The possibility of becoming a professional singer gradually became a goal they held for themselves. This objective became part of their identity and they carried this ambition into their next career stage; breaking into the labour market of professional singing. 


\section{Stage 2: Breaking In}

Early entrances to the labour market are often met with struggle and uncertainty; however, those singers who were focused on achieving their career goal of elite singing found routes through that uncertainty to establish their presence and strengthen their skills and reputations. Most singers spent several years balancing non-arts work with auditioning, undertaking costly studies, and pursuing an unwavering absorption in the craft. This is in line with Bennett's (2008) findings that musicians have traditionally taken on a portfolio of roles to supplement their incomes and to gain a higher status.

Singers in our study expressed complete dedication to their craft, including referring to their pursuit as 'a calling'. Similarly, a study by Dobrow and Heller (2012) followed a group of highly trained musicians for seven years and found that they viewed a music career as a calling that became inseparable from their identity. Likening a 'calling' to the sounds of the mythical singing sirens, Dobrow and Heller (2012) warn that the quest may be enchanting but that skills and knowledge were essential to navigating a career path that anticipated and avoided a possible shipwreck. The imparting of these career skills has not been ubiquitous in performing arts training. In our study the singers, whilst focused on the complex craft required of elite singing, recall few discussions in their pre-career stage about the type of labour market they would attempt to enter and even less about strategies for sustaining a lifelong practice of music making in the creative industries.

Having embarked on a career trajectory toward professional status, singers needed to find a way to break into the industry. Breaking into creative careers is a complex, hidden, and rarely investigated part of the career cycle. However, Jones $(1996,2002)$ provides a model based on the career patterns of practitioners in the film industry that serves as a solid description of this process. Jones found that not only are complex skills in specialist creative practice required of aspirants, but they need skills in interpersonal communication, managing reputational signals, deft handling of gatekeeper relationships, persistence, and the maintenance of intrinsic motivation. These skills help support creative practitioners as they cope with precarious work opportunities, low payments for work, and high levels of competition. As one participant-singer said in our interviews, 'Whether you were suitable for handling the type of work and market you were heading into was never discussed at my music training college' (F/010512/13). Jones $(1996,2002)$ is one of several researchers (Bennett, 2008, 2012; Bridgstock, 2005, 2010, 2012; Caves, 2000; Towse 1993) who question whether the training for creative practitioners has equipped them with these capabilities.

The singers in our study engaged in a diverse array of activities in order to break into professional careers. For some, their initial steps were supported by low-level jobs within arts organizations. These opportunities were put to good use as singers were able to see first-hand the operations, both artistically and administratively, of large cultural organizations. Throsby and Zednick (2010) have shown that most artists supplement their creative practice by undertaking administrative, retail, hospitality, and a range of other types of work. Bennett (2008) demonstrates that portfolios of work undertaken by musicians have been a consistent source of financial support for centuries. The casual nature of these types of work arrangements often 
leave creative practitioners, such as singers, the room to work on their skills, attend auditions, and continue to seek opportunities to develop their reputation as an artist.

Regular auditioning and performing for community groups were a plentiful source for gaining information about the profession, networking with those who might offer them work, and furthering skills development. One singer in our study demonstrated the effectiveness of this path. She improved her dance skills amongst community theatre groups and then, in a postgraduate opera course, met the dance captain for the national opera company who observed her advanced dance skills and advised her to audition. As the singer recalled, 'I didn't have many opportunities during the course but the networking meant within a year I had a permanent contract with the national company' (F/150212/7). Coffman and Higgins (2012) have similarly shown that community music-making can be life-changing.

A source of reputation-building for some singers came through prestigious singing competitions. For example, one singer reports that as she was handed the cheque for an award, she was advised to use the money on overseas training and to begin a career in singing. She reflected, 'I didn't even think someone could earn a living as a singer at that stage' (F/220312/9). However, some in the creative arts are wary of competitions as a source for career building because criteria for selection of winners are highly subjective, unstated, and at times judges can be quarrelsome (Beeching, 2010; Caves, 2000; McPherson and Thompson, 1998). Few, if any competitions have criteria that ensure competitors are suited to the demands of the market conditions. However, singers often express their awards in such competitions as stepping stones to breaking into the field. Towse (1993) comments that gatekeepers and hirers will use competition wins as a source of decision making regarding the hiring of emerging artists.

Most singers found their own persistence to be their most valuable asset for breaking into the profession. However, they often relied on external support to maintain their efforts.

Representation by agencies played a part, but was less important than support from teachers, parents, well-connected individuals, and peers at the point of breaking in. In the end, persistence and external recognition of their skills prevailed for the singers in the study. Having entered their professional career as singers, new and exciting challenges lay ahead in the peak stage of their careers.

\section{Stage 3: Peak period}

Classical singers and other performing artists eventually reach a career stage which finds them at the peak of their skills and popularity. At this stage they are usually engaged in elite projects with expert collaborators, and secure earnings and work offers which give rise to a sense of achievement. They are frequently sought after by elite companies and are capable of managing diverse and demanding roles ranging from operatic to music theatre. This period is often recognized only in hindsight as, like many upward climbs, the peak is only relative to the surrounding topography.

Hall (2002) and Jones (1996, 2002) recognize this period for elite practitioners as significant. Hall (2002) denotes the peak period of a career as a complex one requiring constant adjustment 
to possible modifications. Jones' investigation of careers in the film industry found that elite practitioners were capable of managing projects in quick succession, experienced a constant need for travel, and were focused on the maintenance of skills and networks. Other skills identified at this stage include a high level of communication, a large investment of time, industry knowledge, and an ability to comprehend the high levels of competition (Ensher et al., 2002; Jones, 1996, 2002; Towse, 1993).

Both Hall and Jones describe a necessity at this stage to constantly evaluate and improve capabilities in order to continue being successful with elite projects and master new areas of work. For the singers in our study their career achievements, as well as perceived failures, underpinned their outlook on their trajectory. As one singer we interviewed observed 'I was not a superstar but I substituted for many stars and worked with high-level performers, conductors, and directors in iconic venues. These achievements deeply embedded my identity as an elite performer' (F/020312/8). In this stage, singers in our study intensified their identity with the vocation as the craft became ever more central and encompassing of their lives.

The singers' working lives were extremely busy in this peak stage. As they constantly learned new roles and regularly travelled to expensive metropolitan centres, with some receiving industry awards, their specialized careers required intense energy and commitment. Long runs in commercial theatres and regular roles in subsidized companies or choral organisations lead to a sense of security and higher earnings. For most singers such a privileged position had taken considerable time to achieve, and they needed to maintain physical, mental, and emotional fitness to cope with the demands of their highly specialized craft. They were constantly being evaluated by audiences, management, and their own sense of intense conscientiousness. There was an imperative to take on roles, perform at high levels in these, and defend their position against younger competitors. All of these intensive activities leave a singer with little time for well-judged decision-making regarding subsequent career steps (Hall, 2002).

Western society places a high value on art, artists, and associated careers (Abbing, 2012); yet as Jones (1996) describes, artists' careers can be short-lived. In fact, performers at this stage are often reluctant to address matters of change and career trajectory for fear it would jeopardize their career and employment chances (Jeffri and Throsby, 2006; Ryan, 2002). With hindsight, the singers in our study found they relied on anecdotal concepts of career trajectories or models that had become outdated. Restiveness, boredom and stalling begin to make their presence felt; and when the singers attempt to take control of their career trajectories, they are often faced with immense challenges (Menger, 1999). One singer in our study reinforced this finding.

I had seen older generations of singers begin as choristers, grow into supporting or comprimario roles and have a good career. I expected that to be my trajectory . . . I understudied a role for more than 250 performances and not once did I perform the role ... I lask for a meeting with management to discuss my position . . I was told there were hundreds of singers with similar voices to mine and I would be unlikely to receive any further advancement . . . I felt disappointed and stuck. (F/010512/13) 
Exacerbating this lack of control is the fact that there are few programmes to assist performers with career planning. They are therefore left in a position of ameliorating those who would control their career and are 'infantilized' by an industrialized system of performance companies that are more concerned about box office receipts, conservative programming, and corporate professionalism (Crawford, 2015: 28).

Just as the peak of a career may be difficult to judge at the time, so is it also difficult to anticipate its end. Logically there is an inevitable decline from the peak, but managing that transition can be a challenge.

\section{Stage 4: Denouement}

The denouement stage follows the highly specialized, intense, and vocationally exclusive careers the singers experience in their peak stage. Denouement is a French literary term that means untying a knot and bringing threads together in a following epilogue. Denouement has great value as a term to describe this next stage in the performing artist's career, as it is a period of transition away from a sense of being at one's peak. An uneventful career transition from elite performing practice to something else is rare. Although some people deliberately envision this change and plan for it, most singers in our study for whom the average age at this stage of denouement was 36-39 were left vulnerable to an unplanned mid-career transition. The journey toward a new career was therefore complex and hazardous.

Open discourse regarding creative careers and their denouement remains under-exposed. An exception is Oakland's (2010) study of the forced redundancies of seven full-time opera singers in the UK. She found that the singers experienced strong feelings of trauma and resentfulness as they tried to accept their career change and find new directions to continue their engagement in music making. A small number of Oakland's subjects found that singing again, at any level, was too difficult to face.

In our study there was a complexity in the manner and perception of how the participants' singing careers drew to a conclusion. Whether by involuntary or voluntary means the majority of the singers experienced considerable loss, anger, and trauma as they realized that offers for roles were declining or had stopped. For some, their awareness of an impending denouement was obfuscated by industrial practices, in particular the hierarchical and siloed nature of opera companies or the one-size-fits-all approach in commercial theatre (Hesmondhalgh 2007; Hesmondhalgh and Baker, 2011). The singers recall lacking the skill and cogent understanding to negotiate career planning. Extreme busyness in learning and performing roles and concert performances, while beckoning, was sometimes a screen that masked the reality of dealing with a future that would need deliberation, engineering, and forethought. As one singer recalled 'I really didn't know how to discuss the possible dignified exit to my career with my agent or management' (F/220312/9). As intermediaries in the hiring process, singer's agents are engaged for the purpose of finding roles or work, relieving the singer of the time consuming task of work search. However, they are not career designers and have little control over audience tastes and company budgets. Singers may miss the signs of career denouement but agents are not career counsellors. Many singers, then bargain with the industry and themselves, attempting to maintain their career by travelling to other markets (especially 
Europe) to seek new opportunities only to find that, as another singer describes, 'the harsh reality was there was no route to the ambitions I set for myself' (F/010512/13). This awareness often came too late for dealing effectively with this concluding career stage. Planning a career change takes awareness, acceptance of potential change, and having psychological and financial buffers in place to cope with the upheavals. The study found few singers were prepared to address the needs of career denouement.

There are very real issues concerning the emotional well-being and financial security of elite singers as they experience a denouement stage. The singers in our study recall intense feelings of loss, denial, and anger, with many taking between five to seven years to mourn the forfeiture of their fiercely striven career as an elite singer. On reflection, many of the singers realize that they overestimated the probable length of their career. They relied on past and dysfunctional models of career trajectories that were unhelpful and did not create room for accepting change, nor allowed them to conceive of themselves beyond the industrial base of performance.

Strategies and planning for life after absorbing 'one of life's little deaths' (Jeffri and Throsby 2006: 50) were not discussed, and so any preparation for this stage was absent for most of the singers. However, all eventually found their way through this stage and on to other opportunities.

\section{Stage 5: Moving On}

Whether planned or forced, almost all professional performing artists need to move on to something else following denouement. This moving-on stage can be one of renewal, but often involves considerable soul-searching and reskilling. Coming to terms with a change in their career and enacting new directions was difficult, complex, and emotional for most of the singers in our study. Most had little or no buffer, either emotional or financial, to help them through the initial process. However, over time, they began to find new skills and especially new communities in which they could flourish. Often they sought, and were able to, remain close to their craft competencies, aesthetic agendas, and creative practice.

Renshaw (2010) has shown that artists, by working outside the arts sector, can be transformed by engaging meaningfully and with excellence, in a range of contexts, including judicial programs, age care and health, remote and or low socioeconomic communities, yet not without significant changes in the way artists are enculturated and trained. The singers in this study found they needed new skills and to enter communities where their highly specialized skills could be valuable. Leadership was a skill especially required moving forward, yet previous arts experiences had not developed this capability. One singer recalled the changes needed to secure work opportunities after an unsteady start: 'Later I began a new collaboration. I learnt how to pitch an idea, seek funding, manage talent, and administer a company ... It was a great success but we still lost a lot of money' (F/030712/11). While the singers often absorbed new skills and implemented these, the issue of finance was raised by most who endeavoured to start small performance businesses.

Most avenues open to the singers required new vocational skills in enterprise management, pedagogical training, or marketing. These paths often involved steep learning curves in technology and business administration. With these new skills they could begin practices in teaching, small-scale performance enterprises (for example, community recital series, opera 
boot camps), and business ventures. They needed to recast their identities as creative practitioners who connect with communities, rather than as workers relying upon institutional arts organisations for a career framework. Finding steep learning curves in new technologies, the singers learned that an openness to new concepts about how their artistic practice could endure were essential.

Life was still blurry at the time, but I recall meeting someone during that period who suggested starting a semi-professional opera group . . Reality began to strike . . . I could sell, sell, sell my singing career or I could stop reacting to what had happened and take a bold new step ... So I went on to start [a new opera company], and it saved me. Initially there was a large personal debt and the group was disbanded, but it helped me find my creative energy and was a way of addressing some of the things I thought were wrong in the development of young voice artists in this country (F/291011/3).

Exacting lessons were learnt, emotional wounds were shed, and today a vision to train aspiring singers in many skills and capabilities through a small performance enterprise is highly regarded and sustained. Other singers took opportunities to retrain, either returning to tertiary institutes to complete degrees or begin new ones, and start a journey into different communities that valued their diverse skills. Transference of the skills accumulated as an elite singer, took some time to be recognized as valuable; and on reflection many of the interviewees now identify diverse capabilities which can serve their communities. Other singers took self-devised apprenticeships as a result of their experiences in the theatre industry, and today are successful sole traders operating independent practices, micro businesses or a portfolio of roles as creative practitioners (Arthur et al., 1999).

Maintaining an involvement in the creative industries was a goal for the singers, as they began to realize their careers as elite professional singers were changing. For a limited number of singers, a planned and guided exit was something they looked toward, but most singers faced an end that triggered waves of emotional struggle as they looked for a route toward their new purpose. The majority of the singers in this study found that teaching singing suited their personality and maintained an identification with their craft. Other singers endeavoured to maintain a performance profile by venturing into enterprises that require skills in marketing, business administration, and managing an array of resources. Many of these ventures were unfamiliar and thus taxing on the singers. Cultivating networks and skills that sustained or even began to help turn a profit would prove an onerous task.

Recent studies investigating skill sets required for those looking to sustain a career in performing arts have turned their attention to the readiness and comprehension that creative practitioners have about sustaining careers in an economic landscape that challenges traditional concepts of artists learning and practising. It suggests that the training of artists, including those destined to be elite classical singers, will need to include vocational skills which augment capabilities, and promote less siloed and broader engagement in artistic practices and career longevity and diversity (Beckmann, 2010, Bridgstock, 2005, 2010, 2012; Gotsi et al., 2010).

\section{Conclusions and recommendations}


The demands of elite performing arts careers are experienced in a labour market that has distinct and selective practices which can expand some careers at particular stages, and limit others at another stage. As outlined in this chapter, prominent stages of performing arts careers are: pre-career, where training and motivations are the focus; breaking in, where performers seek to establish themselves in the professions; peak period, in which work lives are busy and performers develop a sense of achievement; denouement, when work opportunities diminish and performers struggle to develop new career directions, and; moving on, where acceptance that the performing career has passed occurs and new opportunities are embraced.

Most particular for the career trajectories of performing arts practitioners is the denouement stage which often arrives unexpectedly. Performing arts careers are time-limited, as are other embodied careers like being an elite sportsperson or a labourer, and it seems from our study that too often there is little recognition of this and thus poor planning for moving onto further career stages. For a number of the singers in our study, success was brought to a sudden end against a backdrop of changing managerial practices, and for others a sense that the mechanics of arts bureaucracies have limiting channels. The singers we interviewed were mostly unprepared for the changes that would complicate their lives, as their embodied and cherished careers as elite singers began to peel away.

In our study we encouraged singers to reflect on their skills and the sort of transition they experienced, and offer some advice to emerging singers. A common theme was the need for an open discourse that a singer's career can be quite short, yet the singers recognized the reluctance of emerging singers to face this issue. Two singers reflected on this: 'the industry can be abusive ... with a "tough it out" attitude ... Taking counselling should not be seen as a weakness' (F/291011/3). Another advised that 'older artists ought to take out a paper and pen and write out plans and contingencies ... it's unwise not to consider an end ... and then feel let down' (M/170412/12). The singers observed that the need for planning, support services, and reskilling was essential to a well-adjusted transition, reinforcing observations by Ebberwin et al. (2004) and Heppner (1998). Following denouement our interviewees were eager to maintain connection with their craft and domain, whether by pedagogical practice or pursuing a performance arts venture.

The interviews demonstrate the need for skills that enable better financial and business literacy and technological competency, and for a broader perspective on how the skills a singer possesses could be transferred to new arenas. The domains of elite sports and dance seem to 
offer better acceptance of the time-framed nature of these highly specialized, embodied creative careers and subsequently offered services for those exiting the field including career planning and counselling services. As Oakland, Macdonald and Flowers (2012: 145) noted, 'sports and dance have recognized systems in place to guide individuals through the inevitable transition. Career transition is now a fundamental issue for musicians worldwide ... we have an obligation to strive for greater understanding of the issues specific to musicians'. To date, this situation seems little improved.

In this chapter, we have described how creative careers in the performing arts follow a somewhat unique trajectory that is driven by specific labour market conditions. We have argued that the uncertainty of performing arts careers is complicated by many factors and that the lack of consideration of longevity and career sustainability exacerbates the problem. Professional singers experience highly intense career stages, yet often neglect career planning. These reported experiences lead us to suggest there must be more to creative careers than an impetus for creativity.

\section{References}

Abbing, H. (2011), 'Poverty and support for Artists', in R. Towse (ed.), A Handbook of Cultural Economic, second edition, Northampton, MA, USA: Edward Elgar Publishing, pp. 344-9.

Arthur, M., K. Inkson, and J. Pringle (1999), The New Careers: Individual Action and Economic Change, London, UK: Sage Publications.

Baillie, P. (1993), 'Understanding Retirement from Sports: Therapeutic Ideas for Helping Athletes in Transition', The Counseling Psychologist, 21, 399.

Bartleet, B.L., R. Letts, P. Dunbar-Hall and H. Schippers (2008), 'Sound links: Community music in Australia', Brisbane, Austrlia: Griffith University.

Beckmann, G. (2010), 'Adventuring' Arts Entrepreneurship Curricula in Higher Education: An examination of Present Efforts, Obstacles, and Best Practices', The Journal of Arts Management, Law and Society, 37 (2), 87-112.

Beeching, A. (2010), Beyond Talent: Creating a Successful Career in Music, Oxford, UK: Oxford University Press.

Bennett, D. (2008), Understanding the Classical Music Profession. The Past, the Present and Strategies for the Future, Farnham, UK: Ashgate.

Bennett, D. (ed.) (2012), Life In the Real World. How to make Music Graduates Employable, Champaign, IL, USA: Common Ground.

Bridgstock, R. (2005), 'Australian Artists, Starving and Well Nourished: What can we learn 
from the prototypical Protean Career?', Australian Journal of Career Development, 14 (5), 40-48.

Bridgstock, R. (2010), 'Skills for creative industries graduate success'. Education and Training, $53(1), 9-26$.

Bridgstock, R. (2012), 'Not a dirty word: Arts Entrepreneurship and higher education', Arts and Humanities in Higher Education, 12 (2-3), 122-37.

Callaghan, J., S. Emmons, and L. Popiel (2012), 'Solo Voice Pedagogy', in G. McPherson and G. Welch (eds), The Oxford Handbook of Music Education, vol.1, Oxford, UK: Oxford University Press, pp. 559-80.

Caves, R. (2000), Creative Industries. Contracts between Art and Commerce, Boston, MA, USA: Harvard University Press.

Colin, M. (2014), 'Before what age does it take to be an opera singer?', sfcv.org, accessed 10 December 2017 at https://www.sfcv.org/article/age-before-what-does-it-take-to-be-anopera-singer

Crawford, T. (2015), 'Feudal Positions and the Pathology of Contentment: Sites of Disconnection for Australian Theatre Actors', in M. Seton (ed.), About Performance: The Lives of Actors, no.13, Sydney, Australia: University of Sydney, Department of Theatre and Performance, pp. 23-231.

Coffman, D. and L. Higgins (2012), 'Community Music Ensembles', in G. McPherson and G. Welch (eds), The Oxford Handbook of Music Education, vol.1, Oxford, UK: Oxford University Press, pp. 844-59.

Daykin, N. (2005), 'Disruption, dissonance and embodiment: creativity, health and risk in music narratives', Health: An Interdisciplinary Journal for the Social Study of Health, IIIness and Medicine, 9 (1), 67-87.

Dobrow, S. and D. Heller (2012), 'A Siren song? A longitudinal study of the role of calling and perceived ability in career pursuit', in Academy of Management Conference, 2012, Boston, USA, accessed April 2016 at: http://eprints.Ise.ac.uk/65984/.

Ebberwin, C, T. Krieshok, J. Ulven, E. Prosser (2004), Voices in Transition: Lessons on Career Adaptability', The Career Development Quarterly, 52 (4), 292-308.

Ensher, E., S. Murphy and S. Sullivan (2002), 'Boundaryless Careers in Entertainment: Executive Women's experiences', in M. Peiperl, M. Arthur, and N. Anand (eds), Career Creativity: Explorations in the Remaking of Work, Oxford, UK: Oxford University Press, pp. 229-55.

Gotsi, M., C. Andriopolous, M.W. Lewis, and A. Ingram (2010), 'Managing Creatives: Paradoxical approaches to identity regulation', Human Relations, 63 (6), 781 805. 
Grove, J.R., D. Lavelle and S. Gordon, S (1997), 'Coping with Retirement from Sport: The Influence of Athletic Identity', Journal of Applied Sport Psychology, 9 (2), 191-203.

Hall, D. (2002), Careers In and Out of Organisations, Thousand Oaks, CA, USA: Sage Publications.

Hallman, R. J. (1965), 'Aesthetic Motivation in the Creative Arts.' The Journal of Aesthetics and Art Criticism, 23 (4), 453-59.

Heppner, M (1998), 'Adults in Involuntary Career Transition: An Analysis of the Relationship Between the Psychological and Career Domains', Journal of Career Assessment, 6 (3), 329- 46.

Hesmondhalgh, D. (2007), The Cultural Industries, second edition, London, UK: Sage Publications.

Hesmondhalgh, D. and S. Baker (2011), Creative Labour: Media work in three cultural industries, Abingdon, UK: Routledge.

Jeffri, J. and D. Throsby (2006), 'Life after Dance: Career Transition of Professional Dancers', International Journal of Arts Management, 8 (3), 54-62.

Jones, C. (1996), 'Careers in Project Networks: The Case of the Film Industry', in M. Arthur and D. Rousseau (eds), The Boundaryless Career, Oxford, UK: Oxford University Press, pp. 58-75.

Jones, C. (2002), 'Signalling Expertise: How Signals Shape Careers in Creative Industries', in M. Peiperl, M. Arthur and N. Anand (eds), Career Creativity: Explorations in the Remaking of Work, Oxford, UK: Oxford University Press, pp. 209-28.

McPherson, G., J. Davidson and R. Faulkner (2012), Music In Our Lives: Rethinking Musical Ability, Development and Identity. Oxford, UK: Oxford UniversityPress.

McPherson, G.E. and W. Thompson (1998), 'Assessing Music Performance: Issues and Influences', Research Studies in Music Education, 10 (1), 12-24.

McPherson, G. and Welch, Graham (2012), 'Introduction and commentary - music education and the role of music in people's lives', Oxford Handbook of Music Education, vol. 1, Oxford, UK: Oxford University Press, pp. 5-20.

Menger, P.C. (1999), 'Artistic Labor Markets and Careers', Annual Review of Sociology, 25 (1), 541-74.

Oakland, J. (2010), 'Giving Voice': Enforced Occupational Change in Opera Choristers, Unpublished Thesis, Glasgow Caledonian University, UK. 
Oakland, J., R.A. MacDonald and P. Flowers (2012), 'Re-defining 'Me': Exploring career transition and the experience of loss in the context of professional opera choristers', Musica Scientia, 16 (2), 135-47.

Pettinger, L. (2015), 'Embodied labour in music work', The British Journal of Sociology, 66 (2), 283-300.

Plotkin, F. (2016), 'How old is too old for the opera stage?', wqxr.org, accessed 10 December 2017 at http://www.wqxr.org/story/how-old-too-old-opera-stage/.

Robinson, K. and L. Aronica (2009), The Element: How Finding Your Passion Changes Everything, London, UK: Penguin Books.

Renshaw, P. (2010), Engaged Passions. Searches for Quality in Community Contexts, Delft, The Netherlands: Eburon Academic Publishers.

Ryan, S.M. (2002), 'Life-Span Development Perspectives of the Professional Dance Career', Unpublished Thesis, Queensland University of Technology, Brisbane, Australia.

Simeonova, J. (2017), 'Who's afraid of the aging singer?', Schmopera, accessed 10 December 2017 at https://www.schmopera.com/whos-afraid-of-the-agingsinger 21

Spruce, G. and Odena, O. (2012), 'Commentary - Music learning and teaching during adolescence; ages 12-18', in G. McPherson and G. Welch (eds), Oxford Handbook of Music Education, vol. 1, Oxford, UK: Oxford University Press, pp. 437-40.

Throsby, D. and A. Zednick (2010), 'Do you really expect to be paid? An economic study of professional artists in Australia', Sydney, Australia: Australia Council for the Arts.

Towse, R. (1993), Singers in the marketplace: The Economics of the Singing Profession, Oxford, UK: Clarendon Press. 